\title{
Transmission routes of visceral leishmaniasis in mammals
}

\author{
Vias de transmissão da leishmaniose visceral em mamíferos
}

\author{
Vinícius Vasconcelos Gomes de Oliveira ${ }^{I^{*}}$ Leucio Câmara Alves ${ }^{I I}$ \\ Valdemiro Amaro da Silva Junior ${ }^{\mathrm{I}}$
}

\section{- REVIEW -}

\section{ABSTRACT}

Visceral leishmaniasis (VL) is a chronic disease caused by Leishmania infantum. The major sites of parasite localization in infected animals are the secondary lymphoid organs, bone marrow and cutaneous tissue. However, reports exist on the detection of the parasite in the organs of the male and female genital system. The main route of transmission is related to the hematophagous sandfly vectors of the genus Lutzomyia (New World) and Phlebotomus (Old World). However, other routes of transmission may be mentioned, such as sexual, vertical, hematogenic without vector and others involved in $V L$ epidemiology. Thus, the current article reviews the main forms of transmission of visceral leishmaniasis in mammals.

Key words: Leishmania sp, dogs, sexual transmission, vertical transmission.

\section{RESUMO}

A leishmaniose visceral (LV) é uma doença crônica causada pelo protozoário Leishmania infantum. Os principais sítios de localização do parasito nos animais acometidos pela LV foram órgãos linfoides primários, secundários e tegumento. Contudo, existem relatos da deteç̧ão do parasito em órgãos do sistema genital masculino e feminino. A principal via de transmissão decorre da ação hematófaga de vetores flebotomíneos pertencentes aos gêneros Lutzomyia (Novo Mundo) e Phlebotomus (Velho Mundo). Todavia, outras formas de transmissão podem ser relacionadas, como as vias sexual, vertical, hematógena não vetorial e ainda existe a possibilidade de outros vetores estarem envolvidos na epidemiologia da doença. Dessa forma, a proposta deste artigo foi revisar as principais formas de transmissão da leishmaniose visceral em mamíferos.

Palavras-chave: Leishmania sp., cães, transmissão sexual, transmissão vertical.

\section{INTRODUCTION}

VL is an important parasitic zoonosis and domestic dogs are the main reservoir of the disease, particularly in urban areas (DINIZ et al., 2008). It is caused by Leishmania infantum (synonym to $\boldsymbol{L}$. chagasi) with tropism for the mononuclear phagocyte system (NEVES, 2005; CHAPPUIS et al., 2007).

The disease is usually transmitted by the hematophagous activities of sandflies belonging to the genera Lutzomyia (New World) and Phlebotomus (Old World) (MURRAY et al., 2005). However, alternative routes of transmission have been described in dogs and man (TURCHETTI et al., 2014). In dogs, there are reports of sexual (SILVA et al., 2009a) and vertical transmission (NAUCKE \& LORENTZ, 2012), by blood transfusion (DE FREITAS et al., 2006) and by other vectors such as fleas and ticks which may be involved in the epidemiology of the disease (MORAIS et al., 2013).

Alternative routes of infection jeopardize the control strategies and eradication of VL based on vector elimination. In fact, they are inefficient since the parasite $\boldsymbol{L}$. infantum would still maintain its lifecycle transmitted by the breeding of positive stray dogs (SILVA et al., 2009a).

Epidemiologically, infection in dogs is more prevalent than in man, and there is a large number of asymptomatic animals which host parasites in the dermis (BONATES, 2003). The VL in dogs is considered a chronic disease characterized

\footnotetext{
'Departamento de Morfologia e Fisiologia Animal, Universidade Federal Rural de Pernambuco (UFRPE), Rua Dom Manoel de Medeiros, s/n, Dois Irmãos, 52171-900, Recife, PE, Brasil. E-mail: vinicius-vasconcelos@hotmail.com. *Corresponding author.
}

IIDepartamento de Medicina Veterinária, UFRPE, Recife, PE, Brasil. 
by the emergence of several clinical signs such as lymphadenomegaly, dermatopathies (SOLANOGALLEGO et al., 2009), hepatosplenomegaly, onychogryphosis (ALBUQUERQUE et al., 2007) and ophtalmopathies (BRITO et al., 2006). In addition to these classical lesions, the parasite eventually causes damage to the reproductive system of male (MIR et al., 2012) and female dogs (OLIVEIRA, 2013). It may even be detected in the semen (DINIZ et al., 2005) and the placenta (DUBEY et al., 2005), respectively featuring the occurrence of sexual and vertical transmission.

Since different alternative routes of VL transmission exist in mammals, current analysis will deal with the main forms of transmission of $\boldsymbol{L}$. infantum due to the epidemiological importance for the maintenance of the parasite's life, especially in vector-free areas.

\section{Classical pathway of VL transmission}

L. infantum is a biphasic parasite, with heteroxenous life cycle, or rather, completed in two hosts: the sandfly vector (L. longipalpis in the New World), which hosts the parasite in a flagellated promastigote extracellular form; and the mammalian host in which the intracellular amastigote form develops (BARATA et al., 2004; TOMÁS \& ROMÃO, 2008; SOLANO-GALLEGO et al., 2009).

The primary transmission of VL between mammals occurs indirectly through the vector which is infected during blood meal in an infected human or animal, by ingesting amastigotes of $\boldsymbol{L}$. infantum in the dermis (BARATA et al., 2004). The amastigotes become promastigotes inside the insect gut between 24 to 48 hours after ingestion. In their turn, the promastigotes reproduce and migrate to the esophagus and pharynx. During the next blood meal they are inoculated into the dermis of the vertebrate host (KAMHAWI, 2006). The salivary gland secretions of the $\boldsymbol{L}$. longipalpis have a potent vasodilator peptide, called maxadilan, which is released in the host's dermis during the blood meal, and thus facilitating the infection (LERNER et al., 1991; LERNER \& SHOEMAKER, 1992).

After infection of the vertebrate host by the parasite's promastigotes, the latter are engulfed by macrophages and become amastigotes. The amastigotes reproduce in the macrophages, breakup the macrophages and are released within the extracellular medium, where they are again engulfed by other macrophages (HANDMAN \& BULLEN, 2002).

Sexual transmission of VL

The first report on sexual transmission of VLoccurred in a human patient in the United Kingdom.
The study reported that in an area without vectors or autochthonous cases of the disease, a woman, who had never been abroad, developed genital lesions containing amastigotes of $\boldsymbol{L}$. infantum. The analysis showed that infection occurred because her husband had been infected by parasite in the Sudan twelve years before (SYMMERS, 1960).

In dogs, RIERA \& VALLADARES (1996)

suggested that the venereal transmission occurred in this species, since $\boldsymbol{L}$. infantum was isolated in the animals' semen. In their study, they reported that three Beagle males were experimentally inoculated with $\boldsymbol{L}$. infantum and after infection had been confirmed by serological methods, direct exams and cell culture of lymph nodes obtained by puncture, the semen was collected and cultivated in a NNN medium (NovyMacNeal-Nicolle).

Besides the isolation of $\boldsymbol{L}$. infantum in canine semen (RIERA \& VALLADARES, 1996), several other studies have shown that the parasite features tropism for the male reproductive system of dogs (DINIZ et al., 2005; AMARA et al., 2009; BENITES et. al., 2011) producing a local immune response (BENITES et al., 2011) and favoring the appearance of $\boldsymbol{L}$. infantum in the semen of the animals (DINIZ et al., 2005).

Male dogs naturally infected by $\mathbf{L}$. infantum reveal no macroscopic changes in the genital organs, even though histological lesions are extant (AMARA et al., 2009). Lesions are characterized by chronic inflammatory reactions in all organs who belong to this system (OLIVEIRA, 2013), degenerative atrophy of the seminiferous epithelium (PIZARRO et al., 1989; DINIZ et al., 2005; AMARA et al., 2009), interstitial fibrosis with thinning of the epididymal epithelium (AMARA et al., 2009), prostatitis (MIR et al., 2012) and azoospermia (DIAZ et. al., 1982).

Besides lesions in the internal genital organs, amastigotes of $\boldsymbol{L}$. infantum has also been reported in the dog's glans penis associated to transmissible venereal tumor (CATONE et al., 2003, MARINO et al., 2012) and prepuce (DINIZ et al., 2005), providing an inflammatory reaction with the predominance of macrophages in these regions. These studies become strongest the possibility of the sexual transmission of VL. On the other hand, it is debatable whether disease transmission occurs through the contaminated semen or by the transference of $\boldsymbol{L}$. infantum amastigotes derived from the male's external genitalia during canine highly traumatic mating (SILVA et al., 2009a).

In female dogs, the vulvar dermatitis was the only important lesion suggesting that $\boldsymbol{L}$. 
infantum does not have tropism by female genital system (SILVA et al., 2008). However, other studies showed that all the organs of the genital system from female dogs naturally infected by $\boldsymbol{L}$. infantum, with the exception of the ovaries, have lesions with high parasitic load levels in all the organs (ROSYPAL et al., 2005; OLIVEIRA, 2013). Consequently, the parasite has a tropism for the genital organs of the male (DINIZ et al., 2005) and female dogs (OLIVEIRA, 2013).

In experimental procedures without biologic vectors, female dogs negative to $L$. infantum were mated with male dogs naturally infected resulting in $25 \%$ of female dogs serologically positive to Leishmania spp. and $50 \%$ of them were PCR positive (Silva et al., 2009a). According to SILVA et al. (2009a), the sexual transmission was a one-way event despite the fact that they did not performed the experiment in reverse. However, ROSYPAL \& LINDSAY (2005) showed that female BALB/C mice experimentally infected with $\boldsymbol{L}$. infantum and positive to PCR and serological test transmitted the parasite to male mice which shared the same cage.

\section{Vertical transmission of VL}

The vertical transmission of VL in humans was described in children born of infected mothers living in endemic areas (LOW \& COOKE, 1926; BLANC \& ROBERT, 1984). On the other hand, the transmission route is theoretically supported in dogs by the presence of $\boldsymbol{L}$. infantum in pregnant uterus (ROSYPAL et al., 2005), fluid and fetal tissues (CARACAPPA et al., 2000), placental trophoblast (DUBEY et al., 2005) and organs of pups born of infected female dogs (PANGRAZIO et al., 2009).

The first report on the vertical transmission in dogs was given by MANCIANTI \& SOZZI (1995) who isolated $\boldsymbol{L}$. infantum in samples of the liver, spleen and lymph node of a neonate born of an infected female dog. This transmission route was investigated by ANDRADE et al. (2002) who used 63 puppies born to 18 infected female dogs to detect the parasite by parasitological, histopathological and PCR tests in samples of the spleen, liver, lymph nodes and bone marrow. According to the authors, no sample from the puppies proved to be positive and thus the vertical transmission of VL could not be confirmed. However, more recent studies demonstrated that this kind of transmission would be possible in dogs (MASUCCI et al., 2003; DUBEY et al., 2005; ROSYPAL et al., 2005; GIBSON-CORLEY et al., 2008; PANGRAZIO et al., 2009; SILVA et al., 2009b; FREEMAN et al., 2010; BOGGIATTO et al., 2011; NAUCKE \& LORENTZ, 2012).
L. infantum transmission by infected females to puppies does not seem to be related to clinical status during pregnancy. In this case, infection rarely promotes the emergence of clinical signs during the first month of life in dogs (MASUCCI et al., 2003). The parasite migration from mothers to puppies during the pregnancy may occur through the transplacental route since the DNA of $\boldsymbol{L}$. infantum was detected by PCR in the pregnant uterus (ROSYPAL et al., 2005), Further, amastigotes have already been reported in the placental trophoblast (DUBEY et al., 2005).

Since puppies born of infected mothers hardly have any clinical signs (MASUCCI et al., 2003), there are also no histological lesions related with VL in canine fetal organs from positive female dogs (PANGRAZIO et al., 2009). Although no structural changes in the liver, spleen, lymph nodes, bone marrow, kidney and heart have been registered, amastigotes were reported in all organs, except kidney and heart (PANGRAZIO et al., 2009). Similarly as described by MASUCCI et al. (2003), it was observed that there was no difference in the potential transmission of VL when compared pregnant female dogs symptomatic or not, being also possible to observe a high frequency of placental transmission (PANGRAZIO et al., 2009).

In turn, some reports demonstrated infection by $\boldsymbol{L}$. infantum in stillborns or newborns of naturally infected female dogs (GIBSON-CORLEY et al., 2008; FREEMAN et al., 2010; BOGGIATTO et al., 2011). Further, puppies born of naturally infected female dogs showed specific $\mathrm{CD}^{+} \mathrm{T}$ cell proliferative responses against $L$. infantum. This fact suggests a specific immune response against the parasite (BOGGIATTO et al., 2011).

The resistance to leishmaniasis is associated with an intense Th1 type response. On the other hand, immunosuppression is necessary to avoid immune reaction against fetal antigens during pregnancy. Therefore, the natural change that occurs in the immune response pattern during the pregnancy from Th1 to Th2 type may increase the severity of disease in the female dogs and the vertical transmission VL risk (ROSYPAL et al., 2005).

The prevalence of the VL among Foxhound dogs in the United States is remarkable since the sexual and vertical transmission could be responsible for the maintenance of the disease in a non endemic area (PETERSEN, 2009). The VL is an emerging problem among some dog breeds in this country, particularly in the case of this breed dog, with a more than $20 \%$ prevalence based on quantitative PCR (BOGGIATTO et al., 2011). This 
condition occurs in an area where it was not possible to determine whether the species of sandflies were competent as biological vectors for $\boldsymbol{L}$. infantum. Therefore, they may not have contributed towards the maintenance of the disease in this particular breed. Thus, the manner $\boldsymbol{L}$. infantum has been transmitted in dogs in the United States is currently unknown. However, there are reasons to support sexual and vertical transmissions in the maintenance of the disease (PETERSEN \& BARR, 2009).

Hematogenous transmission without vector

Blood transfusion is a common practice in veterinary medicine mainly when the animals have clinical signs related to anemia and hemorrhage (HOSGOOD, 1990). In this case there is a great possibility of transmission of the infectious agents, particularly protozoa, due to their long incubation periods, subclinical persistence in infected animals and possibility of remaining viable in blood stocks (OWENS et al., 2001, TABAR et al., 2008).

The VL transmissions through blood transfusion have been documented in different breeds of dogs that received blood from English Foxhounds donors (OWENS et al., 2001). In this study, the authors do not recommend dogs belonging to this breed as blood donors in North America due to the high prevalence of VL in the animals.

In Spain, TABAR et al. (2008) detected DNA of $\boldsymbol{L}$. infantum by quantitative PCR in $19.6 \%$ of samples from a canine blood bank in an endemic area and demonstrated that infection by $\boldsymbol{L}$. infantum is commonly found in canine blood donors in the region. Further, hamsters (Mesocricetus auratus), inoculated with blood and monocyte suspension from dogs naturally infected by $\boldsymbol{L}$. infantum, developed clinical signs and infection after a 6-month post-inoculation period (DE FREITAS et al., 2006). Results suggest that blood donors should be monitored regularly and rigorously against $\boldsymbol{L}$. infantum so that disease dissemination by blood transfusion would be avoided (DE FREITAS et al., 2006).

Transmission by alternative vectors

The vectorial capacity of the other arthropods may be enhanced by the epidemiological characteristics of VL that allow the close association of ectoparasites with infected dogs (COUTINHO et al., 2005). The above reinforces the theory of SHERLOCK (1964) who reported that transmission could probably be made by other vectors when sandflies are absent. Ticks (Rhipicephalus sanguineus) and fleas (Ctenocephalides felis felis) are among these possible alternative vectors (COUTINHO et al., 2005; COUTINHO \& LINARDI, 2007; MORAIS et al., 2013).

The hypothesis of transmission of VL in dogs by ticks was studied in France in the early twentieth century by BLANC \& CAMINOPTEROS (1930). These authors did an experimental infection in $\boldsymbol{R}$. sanguineus, which were able to maintain viable $\boldsymbol{L}$. infantum. On the other hand, it was demonstrated in the USA, under experimental conditions, that ticks may be infected by L. infantum after blood feeding on an infected dog. Amastigotes ingested during the blood meal may develop into promastigotes and survive for several weeks in the gut of the ectoparasite (MCKENZIE, 1984).

In Brazil, the infectivity of $\boldsymbol{L}$. infantum in ticks was confirmed by experimental inoculation of macerated positive ticks in hamsters (M. auratus) (COUTINHO et al., 2005).More recently, kDNA was detected in the salivary gland of $\boldsymbol{R}$. sanguineus collected from seropositive dogs to Leishmania sp. (DANTAS-TORRES et al., 2010a). Furthermore, the DNA of $\boldsymbol{L}$. infantum has been found in dogs and ticks that were parasitizing these animals (MORAIS et al., 2013). These results, however, did not confirm the vectorial capacity of this species, since the maintenance of the parasite epidemiological cycle and transmissibility for dogs have not been proved. On the other hand, DANTAS-TORRES et al. (2010b) infected teleogines of $\boldsymbol{R}$. sanguineus with promastigotes of $\boldsymbol{L}$. infantum and eggs and larvae of these females were positive by PCR. Results reveal that the parasite may be maintained during the different developing stages.

The $\boldsymbol{C}$.felisfelis flea has also been researched due to its probable participation in the epidemiology of VL (COUTINHO \& LINARDI, 2007, FERREIRA et al., 2009), but with less scientific basis than those for ticks. In these two studies, fleas collected from dogs naturally infected by $\boldsymbol{L}$. infantum were macerated and inoculated in hamsters (M. auratus) orally or intraperitoneally. In the two studies, the hamsters became positive in molecular and serological tests. On the other hand, the possibility of oral transmission of $\boldsymbol{L}$. infantum by fleas cannot be verified due to the possibility of cross-reactivity between Leishmania and Leptomonas by PCR and indirect immunofluorescence test (COUTINHO \& LINARDI, 2007).

\section{CONCLUSION}

Although health authorities only consider the transmission of VL by sandflies, other routes may have epidemiological significance, mainly in areas 
without biological vectors. Among the transmission routes currently studied, the sexual and vertical routes may be highlighted. The participation of other biological vectors, such as ectoparasites in dogs, in the spread of disease still needs scientific confirmation. In the case of blood transfusion, a strict control and monitoring are necessary for blood donor dogs to prevent infection by $\boldsymbol{L}$. infantum .

\section{ACKNOWLEDGEMENTS}

The authors thank Fundação de Amparo à Ciência e Tecnologia do Estado de Pernambuco (FACEPE) for the financial support (Process n ${ }^{\circ}$ IBPG05575.05/12).

\section{REFERENCES}

ALBUQUERQUE,A.R.etal.Aspectos clínicos de cães naturalmente infectados por Leishmania (Leishmania) chagasi na Região Metropolitana do Recife. Clínica Veterinária, v.71, p.78-80, 2007. Available from: <http://www.revistaclinicaveterinaria.com.br/ edicao/2007/novembro-dezembro.html>. Accessed:Ago. 16, 2014.

AMARA, A. et al. Etude histologique des lésions testiculaires chez les chiens leishmaniens. Revue de Médecine Vétérinaire, v.160, n.1, p.54-60, 2009. Available from: <http://www.revmedvet. com/2009/RMV160 54 60.pdf>. Accessed: Ago. 16, 2014.

ANDRADE, H.M. et al. Leishmania (Leishmania) chagasi is not vertically transmitted in dogs. Veterinary Parasitology, v.103, p.71-81, 2002. Available from: <http://www.sciencedirect.com/ science/article/pii/S0304401701005520>. Accessed: Ago. 16, 2014. doi: 10.1016/S0304-4017(01)00552-0.

BARATA, R.A. et al. Phlebotomine sandflies in Porteirinha, an area of American visceral leishmaniasis transmission in the state of Minas Gerais, Brazil. Memórias do Instituto Oswaldo Cruz, v.99, n.5, p.481-487, 2004. Available from: $<$ http://www. scielo.br/scielo.php?pid=s0074-02762004000500004\&script $=$ sci arttext>. Accessed: Ago. 16, 2014. doi: 10.1590/S007402762004000500004

BLANC, C.; ROBERT, A. Cinquième observation de kala-azar congénital. Presse Médicale, v.13, p.1751, 1984. Available from: $<$ http://www.ncbi.nlm.nih.gov/pubmed/6235503>. Accessed: Ago. 16, 2014.

BLANC, G.; CAMINOPTEROS, J. La transmission du Kala-Azar méditerranéen par une tique: Rhipicephalus sanguineus. Comptes Rendus de l'Académie des Sciences, v.191, p.1162-1164, 1930.

BOGGIATTO, P.M. et al. Transplacental transmission of Leishmania infantum as a means for continued disease incidence in North America. PLoS Neglected Tropical Diseases, v.5, p.1019, 2011. Available from: <http://www.ncbi.nlm.nih.gov/pmc/ articles/PMC3075227/>. Accessed: Ago. 16, 2014. doi: 10.1371/ journal.pntd.0001019.

BONATES, A. Leishmaniose visceral (calazar). Veterinary News, v.10, n.61, p.04-05, 2003.

BRITO, F.L.C. et al. Ocular alterations in dogs naturally infected by Leishmania (Leishmania) chagasi. Arquivo Brasileiro de
Medicina Veterinária e Zootecnia, v.58, n.5, p.768-775, 2006. Available from: $<$ http://www.scielo.br/scielo.php?script=sci artte xt\&pid=S0102-09352006000500011>. Accessed: Ago. 16, 2014. doi: 10.1590/S0102-09352006000500011.

CARACAPPA, S. et al. Identificazione di Leishmania in cagne gravide e tessuti fetali mediante PCR e isolamento: nota preliminare. Atti Società Italiana delle Scienze Veterinarie, v.54, p.213-214, 2000.

CATONE, G. et al. Canine transmissible venereal tumor parasitized by Leishmania infantum. Veterinary Research Communications, v.27, n.7, p.549-553, 2003. Available from: $<$ http://www.springerlink.com/content/v4n5pj0776073621/>. Accessed: Ago. 16, 2014. doi: 10.1023/A:1026047725012.

CHAPPUIS, F. et al. Visceral leishmaniasis: what are the needs for diagnosis, treatment and control? Nature Reviews Microbiology, v.5, p.873-882, 2007. Available from: <http://www.nature.com/ nrmicro/journal/v5/n11/full/nrmicro1748.html>. Accessed: Ago. 13, 2014. doi: $10.1038 /$ nrmicro 1748 .

COUTINHO, M.T. et al. Participation of Rhipicephalus sanguineus (Acari: Ixodidae) in the epidemiology of canine visceral leishmaniasis. Veterinary Parasitology, v.128, p.149-155, 2005. Available from: $<\mathrm{http}: / /$ www.sciencedirect.com/science/article/pii/S0304401704005461>. Accessed: Ago. 13, 2014. doi: 10.1016/j.vetpar.2004.11.011.

COUTINHO, M.T.Z.; LINARDI, P.M. Can fleas from dogs infected with canine visceral leishmaniasis transfer the infection to other mammals? Veterinary Parasitology, v.147, p.320-325, 2007. Available from: $<$ http://www.ncbi.nlm.nih.gov/pubmed/17521814>. Accessed: Ago. 13, 2014. doi: 10.1016/j.vetpar.2007.04.008.

DANTAS-TORRES, F. et al. Detection of Leishmania infantum in Rhipicephalus sanguineus ticks from Brazil and Italy. Parasitology Research, v.106, p.857-60, 2010a. Available from: $<$ http://link.springer.com/article/10.1007\%2Fs00436-010-1722-4>. Accessed: 13 Ago. 2014. doi: 10.1007/s00436-010-1722-4.

DANTAS-TORRES, F. et al. Transovarial passage of Leishmania infantum $\mathrm{kDNA}$ in artificially infected Rhipicephalus sanguineus. Experimental Parasitology, v.125, p.184-185, 2010b. Available from: <http://www.ncbi.nlm.nih.gov/pubmed/20138871>. Accessed: Ago. 31, 2014. doi: 10.1016/j.exppara.2010.02.003.

DE FREITAS, E. et al. Transmission of Leishmania infantum via blood transfusion in dogs: potential for infection and importance of clinical factors. Veterinary Parasitology, v.137, p.159-67, 2006. Available from: $<$ http://www.sciencedirect.com/science/article/pii/S0304401705006035>. Accessed:Ago. 13, 2014. doi: 10.1016/j.vetpar.2005.12.011.

DIAZ, M.P. et al. Lesiones testiculares y epididimarias en La leishmaniasis visceral canina, de presentacion natural. Higia Pecoris, v.4, n.10, p.5-25, 1982.

DINIZ, S.A. et al. Animal reservoirs for visceral leishmaniasis in densely populated urban areas. Journal of Infection in Developing Countries, v.2, n.1, p.24-33, 2008. Available from: $<$ http://www. jidc.org/index.php/journal/article/viewFile/318/178>. Accessed: Ago. 11, 2014. doi: 10.3855/jidc. 318 .

DINIZ, S.A. et al. Genital lesions associated with visceral leishmaniasis and shedding of Leishmania sp. in the semen of naturally infected dogs. Veterinary Pathology, v.42, n.5, p.650-658, 2005. Available from: <http://vet.sagepub.com/ 
content/42/5/650.full.pdf $>$. Accessed: Ago. 13, 2014 . doi: $10.1354 / v p .42-5-650$.

DUBEY, J.P. et al. Placentitis associated with leishmaniasis in a dog. Journal of the American Veterinary Medical Association, v.227, p.1266-1269, 2005. Available from: <http://www researchgate.net/publication/7502033 Placentitis associated with_leishmaniasis_in_a_dog $>$. Accessed: Ago. 11, 2014. doi: $10.2 \overline{4} 60$ /javma. $200 \overline{5} .2 \overline{2} \overline{7} .1266$.

FERREIRA, M.G.P.A.et al. Potential role for dog fleas inthe cycle of Leishmania spp. Veterinary Parasitology, v.165, p.150-154, 2009. Available from: <http://www.ncbi.nlm.nih.gov/ pubmed/19595512>. Accessed: Ago. 11, 2014. doi: 10.1016/j. vetpar.2009.06.026.

FREEMAN, K.S. et al. Leishmaniasis in a dog native to Colorado. Journal of the American Veterinary Medical Association, v.237, p.1288-1291, 2010. Available from: <http://www.ncbi.nlm. nih.gov/pubmed/21118014>. Accessed: Ago. 11, 2014. doi: 2460/ javma.237.11.1288.

GIBSON-CORLEY, K.N. et al. Disseminated Leishmania infantum infection in two sibling foxhounds due to possible vertical transmission. Canadian Veterinary Journal, v.49, p.1005-1008, 2008. Available from: <http://www.ncbi.nlm.nih.gov/pmc/articles/ PMC2553493/\# ffn_sectitle>. Accessed: Ago. 14, 2014.

HANDMAN, E.; BULLEN, D.V.R. Interaction of Leishmania with the host macrophage. Trends Parasitology, v.18, n.8, p.332-334, 2002. Available from: <http://www.cell.com/trends/ parasitology/abstract/S1471-4922(02)02352-8?_returnURL=http $\% 3 \mathrm{~A} \% 2 \mathrm{~F} \% 2$ Flinkinghub.elsevier.com $\% 2$ Fretrieve $\% 2 \mathrm{Fpii} \% 2 \mathrm{FS} 1$ $471492202023528 \% 3$ Fshowall $\% 3$ Dtrue? returnURL $=\mathrm{http} \% 3 \mathrm{~A} \%$ 2F\%2Flinkinghub.elsevier.com\%2Fretrieve\%2Fpii\%2FS 1471492 202023528\%3Fshowall\%3Dtrue>. Accessed: Ago. 11, 2014. doi: 10.1016/S1471-4922(02)02352-8.

HOSGOOD, G. Blood transfusion: a historical review. Journal of the American Veterinary Medical Association, v.197, p.998-1000, 1990.

KAMHAWI, S. Phlebotomine sand flies and Leishmania parasites: friends or foes? Trends in Parasitology, v.22, n.9, p.439-445, 2006. Available from: <http://www.cell.com/trends/parasitology/abstract/ S1471-4922(06)00173-5? returnURL $=\mathrm{http} \% 3 \mathrm{~A} \% 2 \mathrm{~F} \% 2 \mathrm{Flinkingh}$ ub.elsevier.com $\% 2$ Fretrieve $\% 2$ Fpii\%2FS1471492206001735\%3Fsh owall $\% 3$ Dtrue? returnURL $=\mathrm{http} \% 3 \mathrm{~A} \% 2 \mathrm{~F} \% 2 \mathrm{Flinkinghub}$.elsevier. com\%2Fretrieve\%2Fpii\%2FS1471492206001735\%3Fshowall\%3Dt rue>. Accessed: Ago. 11, 2014. doi: 10.1016/j.pt.2006.06.012.

LERNER, E.A. et al. Isolation of maxadilan, a potent vasodilatory peptide from the salivary glands of the sand fly Lutzomyia longipalpis. Journal of Biological Chemistry, v.266, p.11234-11236, 1991. Available from: <http://www.jbc.org/ content/266/17/11234.full.pdf+html $>$. Accessed: Ago. 12, 2014

LERNER, E.A.; SHOEMAKER, C.B. Maxadilan: cloning and functional expression of the gene encoding thipotent vasodilator peptide. Journal of Biological Chemistry, v.26, p.1062- 1066, 1992. Available from: <http://www.jbc.org/content/267/2/1062. long $>$. Accessed: Ago. 12, 2014.

LOW, G.C.; COOKE, W.E. A congenial infection of kala azar. Lancetii, p.1209-1211, 1926.

MANCIANTI, F.; SOZZI, S. Isolation of Leishmania from a newborn puppy. Transactions of the Royal Society of Tropical
Medicine and Hygiene, v.89, p.402, 1995. Available from: $<$ http://www.ncbi.nlm.nih.gov/pubmed/7570879>. Accessed: Ago. 12, 2014. doi: 10.1016/0035-9203(95)90028-4.

MARINO, G. et al. Clinicopathological study of canine transmissible venereal tumour in leishmaniotic dogs. Journal of Small Animal Practice, v.53, p.323-327, 2012. Available from: $<$ http://www.ncbi.nlm.nih.gov/pubmed/22489831>. Accessed: Ago. 14, 2014. doi: 111/j.1748-5827.2012.01201.x.

MASUCCI, M. et al. Canine leishmaniasis in the newborn puppy. Veterinary Research Communications, v.27, supl.1, p.771-774, 2003. Available from: $<$ http://www.springerlink.com/ content/j434w6w7r1k54q57/>. Accessed: Ago. 12, 2014. doi: 10.1023/B:VERC.0000014268.61966.69

MCKENZIE, K.K. A study of the transmission of canine leishmaniasis by the tick, Rhipicephalus sanguineus (Latreille), and an ultrastructural comparison of the promastigotas. 1984. 232f. [PhD Dissertation] Oklahoma - Oklahoma State University.

MIR, F. et al. Subclinical leishmaniasis associated with infertility and chronic prostatitis in a dog. Journal of Small Animal Practice, v.53, p.419-422, 2012. Available from: <http://www. ncbi.nlm.nih.gov/pubmed/22690941>. Accessed: Ago. 12, 2014. doi: $10.1111 /$ j.1748-5827.2012.01224.x.

MORAIS, R.C. et al. Detection of Leishmania infantum in animals and their ectoparasites by conventional PCR and real time PCR. Experimental and Applied Acarology, v.59, p.47348, 2013. Available from: <http://www.ncbi.nlm.nih.gov/ pubmed/23132326>. Accessed: Ago. 12, 2014. doi: 10.1007/ s10493-012-9611-4

MURRAY, H.W. et al. Advances in leishmaniasis. Lancet, v.366, p.1561-1577, 2005. Available from: <http://www.ncbi.nlm.nih. gov/pubmed/16257344>. Accessed: Ago. 12, 2014.

NAUCKE, T.J.; LORENTZ, S. First report of venereal and vertical transmission of canine leishmaniosis from naturally infected dogs in Germany. Parasites \& Vectors, v.5, p.67, 2012. Available from: $<$ http://www.parasitesandvectors.com/content/5/1/67>. Accessed: Ago. 12, 2014. doi: 10.1186/1756-3305-5-67.

NEVES, D.P. Parasitologia humana. 11.ed. São Paulo: Atheneu, 2005. 494p.

OLIVEIRA, V.V.G. Avaliação das lesões inflamatórias e da carga parasitária em órgãos do sistema genital masculino e feminino de cães com infecção natural por Leishmania (Leishmania) infantum (Nicolle, 1908). 2013. 72f. Dissertação (Mestrado em Biociência Animal) - Curso de Pós-graduação em Biociência Animal, Universidade Federal Rural de Pernambuco, PE.

OWENS, S.D. et al. Transmission of visceral leishmaniasis through blood transfusions from infected English foxhounds to anemic dogs. Journal of the American Veterinary Medical Association, v.219, p.1076-1083, 2001. Available from: <http:// www.ncbi.nlm.nih.gov/pubmed/11700704>. Accessed: Ago. 12, 2014. doi: 10.1016/S0887-7963(02)80076-1.

PANGRAZIO, K.K. et al. Tissue distribution of Leishmania chagasi and lesions in transplacentally infected fetuses from symptomatic and asymptomatic naturally infected bitches. Veterinary Parasitology, v.165, p.327-331, 2009. Available from: $<$ http://www.ncbi.nlm.nih.gov/pubmed/19647368>. Accessed: Ago. 10, 2014. doi: 10.1016/j.vetpar.2009.07.013.

Ciência Rural, v.45, n.9, set, 2015. 
PETERSEN, C.A. Leishmaniasis, an emerging disease found in companion animals in the United States. Topics in Companion Animal Medicine, v.24, p.182-188, 2009. Available from: $<\mathrm{http}$ :/ www.ncbi.nlm.nih.gov/pubmed/19945086>. Accessed: Ago. 10, 2014. doi: 10.1053/j.tcam.2009.06.006.

PETERSEN, C.A.; BARR, S.C. Canine leishmaniasis in North America: emerging or newly recognized? Veterinary Clinics of North America: Small Animal Practice, v.39, p.10651074, 2009. Available from: <http://www.ncbi.nlm.nih.gov/ pubmed/19932363>. Accessed: Ago. 10, 2014. doi: 10.1016/j. cvsm.2009.06.008

PIZARRO, M. et al. Lésions testiculaires et épididymaires chez les chiens leishmaniens. Recueil de Medecine Veterinaire, v.165, p.441-447, 1989.

RIERA, C.; VALLADARES, J.E. Viable Leishmania infantum in urine and semen in experimentally infected dogs. Parasitology Today, v.12, p.412, 1996. Available from: <http://www.ncbi. nlm.nih.gov/pubmed/15275299>. Accessed: Ago. 09, 2014. doi: 10.1016/0169-4758(96)90062-9.

ROSYPAL, A.C. et al. Transplacental transmission of a North American isolate of Leishmania infantum in a experimentally infected beagle. Journal of Parasitolology, v.91, p.970-972, 2005. Available from: <http://www.journalofparasitology.org/doi/ abs/10.1645/GE-483R.1?journalCode=para $>$. Accessed: Ago. 09, 2014. doi: 10.1645/GE-483R.1.

ROSYPAL,A.C.; LINDSAY, D.S. Non-sand fly transmission of a North American isolate of Leishmania infantum in experimentally infected BALB/c mice. Journal of Parasitolology, v.91, p.1113-1115, 2005. Available from: <http://www.ncbi.nlm.nih.gov/pubmed/16419756>. Accessed: Ago. 09, 2014. doi: 10.1645/GE-586R.1.

SHERLOCK, I.A. Nota sobre a transmissão da leishmaniose visceral no Brasil. Revista Brasileira de Malariología e Doenças Tropicais, v.16, p.19-26, 1964.

SILVA, F.L. et al. Genital lesions and distribution of amastigotes in bitches naturally infected with Leishmania chagasi. Veterinary Parasitology, v.151, n.1, p.86-90, 2008. Available from:
$<$ http://journals.ohiolink.edu/ejc/article.cgi?issn=03044017\&i ssue $=$ v $151 \mathrm{i} 0001 \&$ article $=86$ gladoabniwlc \&search term $=\%$ 28 refkey $\% 3$ D\%28Silva\%232008\%2386\%23*\%29volkey\% 3D\%2803044017\%23151\%2386\%231\%29\%29>. Accessed: Ago. 10, 2014. doi: 10.1016/j.vetpar.2007.09.032.

SILVA, F.L. et al. Venereal transmission of canine visceral leishmaniasis. Veterinary Parasitology, v.160, p.55-59, 2009a. Available from: $<$ http://www.sciencedirect.com/science/article/pii/ S0304401708006031>. Accessed: Ago. 10, 2014. doi: 10.1016/j. vetpar.2008.10.079.

SILVA, S.M. et al. First report of vertical transmission of Leishmania (Leishmania) infantum in a naturally infected bitch from Brazil. Veterinary Parasitology, v.166, p.159-162, 2009b. Available from: <http://www.ncbi.nlm.nih.gov/pubmed/19733439>. Accessed: Ago. 10, 2014. doi: 10.1016/j.vetpar.2008.10.079.

SOLANO-GALLEGO, L. et al. Directions for the diagnosis, clinical staging, treatment and prevention of canine leishmaniosis. Veterinary Parasitology, v.165, p.1-18, 2009. Available from: $<\mathrm{http} / / \mathrm{www}$. sciencedirect.com/science/article/pii/S0304401709003124>. Accessed: Ago. 13, 2014. doi: 10.1016/j.vetpar.2009.05.022.

SYMMERS, W.S.C. Leishmaniasis acquired by contagion: a case of marital infection in Britain. Lancet, v.16, p.127-132, 1960. Available from: <http://www.ncbi.nlm.nih.gov/pubmed/13836213>. Accessed: Ago. 13, 2014.

TABAR, M.D. et al. Detection of Leishmania infantum by realtime PCR in a canine blood bank. Journal of Small Animal Practice, v.49, p.325-328, 2008. Available from: $<$ http://www. ncbi.nlm.nih.gov/pubmed/18422503>. Accessed: Ago. 13, 2014. doi: $10.1111 /$ j.1748-5827.2008.00542.x.

TOMÁS, A.M.; ROMÃO, S.F. Biologia do parasita. In: SANTOSGOMES, G.; FONSECA, I.P. (Eds.). Leishmaniose canina. Lisboa: Chaves Ferreira, 2008. Cap.1, p.7-26.

TURCHETTI, A.P.et al. Sexual and vertical transmission of visceral leishmaniasis. Journal of Infection in Developing Countries, v.8, p.403-407, 2014. Available from: <http://www.ncbi.nlm.nih.gov/ pubmed/24727504>.Accessed:Ago.13,2014. doi:10.3855/jidc.4108. 